\title{
HUBUNGAN IKLIM DAN ANGKA BEBAS JENTIK DENGAN KEJADIAN DEMAM BERDARAH DENGUE DI PUSKESMAS PUTAT JAYA
}

\author{
Relationship Between Climate And Larva Free Number with Dengue Hemorrhagic Fever \\ Incidence in Putat Jaya Public Health Care
}

\author{
Nurvita Tri Kurniawati, Ririh Yudhastuti \\ Departemen Kesehatan Lingkungan \\ Fakultas Kesehatan Masyarakat Universitas Airlangga \\ Alamat email korespondensi: nurvitakurniawati@gmail.com
}

\begin{abstract}
Dengue Hemorrhagic Fever (DHF) was a disease caused by dengue virus and transmitted by mosquito Aedes aegypti. DHF was still a problem in Putat Jaya Public Health Care. Incidence of DHF affected by environmental factors such as climate and larvae density shown by Larva Free Number. This study was aimed to analyze relationship between climatic factors and Larva Free Number with incidence of DHF in Putat Jaya Public Health Care during 2010-2014. This research was an analytical research and ecology time series study. Time data collection was conducted in May 2016. The climate data (rainfall, temperature, and humidity) obtained from Center for Meteorology, Climatology and Geophysics (BMKG) Surabaya Perak and DHF case as well as Larve Free Number data obtained from Putat Jaya Public Health Care. Correlation test results showed that rainfall has a weak and positive correlation with the DHF incididence $(r=0.141)$. Temperatures has a weak and positive correlation with the DHF incidence $(r=$ 0.301). Humidity has a weak and positive correlation with DHF incidence $(r=0.23)$. Larva Free Number in Putat Jaya Public Health Care was still low that did not reach the national standard ( $\geq 95 \%)$. Larva Free Number has a weak and positive correlation with the DHF incidence $(r=0.078)$. Cooperation between the community and Health Center must be done to control DHF. Community can clean the mosquito nest and Public Health Care must do the dengue controlling programs well.
\end{abstract}

Keywords: Climate, Larva Free Number, Dengue Hemorrhagic Fever 
Demam Berdarah Dengue merupakan penyakit yang disebabkan oleh virus dengue dan ditularkan oleh nyamuk Aedes aegypti yang masih menjadi masalah di Puskesmas Putat Jaya. Kejadian DBD dipengaruhi oleh faktor lingkungan seperti iklim dan kepadatan jentik yang ditunjukkan dengan Angka Bebas Jentik (ABJ). Penelitian ini bertujuan untuk menganalisis hubungan faktor iklim dan ABJ dengan kejadian DBD di Puskesmas Putat Jaya tahun 20102014. Penelitian ini merupakan penelitian analitik dengan jenis penelitian studi ecology time series. Waktu pengambilan data dilakukan pada bulan Mei 2016. Data sekunder yang dibutuhkan adalah data iklim (curah hujan, suhu, dan kelembaban) yang diperoleh dari Badan Meteorologi, Klimatologi dan Geofisika (BMKG) Perak dan data kasus DBD serta data ABJ yang diperoleh dari Puskesmas Putat Jaya. Hasil uji korelasi menunjukkan bahwa curah hujan memiliki kekuatan hubungan lemah dan arah hubungan postif dengan kejadian DBD $(r=0,141)$. Suhu memiliki kekuatan hubungan sedang dan arah hubungan postif dengan kejadian DBD $(\mathrm{r}=0,301)$. Kelembaban memiliki kekuatan hubungan lemah dan arah hubungan postif dengan kejadian DBD $(\mathrm{r}=0,23)$. ABJ Puskesmas Putat Jaya masih rendah dengan ABJ yang tidak mencapai standar Nasional $\geq 95 \%$. Hubungan antara ABJ dengan kejadian DBD menunjukkan kekuatan hubungan lemah dan arah hubungan postif dengan kejadian $\operatorname{DBD}(\mathrm{r}=0,078)$. Perlunya kerjasama antara masyarakat dan pihak puskesmas untuk mengendalikan DBD. Masyarakat dapat melakukan Pemberantasan Sarang Nyamuk (PSN) dan pihak puskesmas melaksanakan program pengendalian DBD dengan lebih baik.

\section{Kata Kunci: Iklim, Angka Bebas Jentik, Demam Berdarah Dengue}

\section{PENDAHULUAN}

Penyakit Demam Berdarah Dengue (DBD) merupakan penyakit berbasis lingkungan yang disebabkan oleh virus dengue DEN-1, DEN-2, DEN-3 dan DEN-4 (Kemenkes RI, 2011). Manusia merupakan dead-end host dalam penyakit DBD. Virus dengue dibawa oleh vektor nyamuk Aedes aegypti dan Aedes albopictus namun masih kurang berperan dibanding nyamuk Aedes Aegypti. Kedua vektor ini memiliki kerentanan terhadap virus dengue, kemampuan untuk mereplikasi virus dan kemampuan untuk menularkannya ke manusia (WHO, 2011).

Penularan penyakit menular seperti DBD dipengaruhi oleh faktor iklim. Hal ini dikarenakan vektor penyakit menular seperti nyamuk dan lalat peka terhadap faktor iklim seperti curah hujan, suhu dan kelembaban (Brisbois dan Ali, 2010). Perubahan iklim yang terjadi akan berpengaruh pada penularan vector borne disease. Variabel iklim yang berhubungan dengan penyakit DBD diantaranya adalah curah hujan, suhu dan kelembaban (Pohan, 2014). Curah hujan yang tinggi mengakibatkan breeding place nyamuk meningkat sehingga risiko penularan DBD meningkat pula (Ibarra et al., 2013). Suhu dan kelembaban berhubungan dengan proses fisiologis dan sistem pernafasan nyamuk Aedes aegypti. Suhu dan kelembaban yang sesuai akan meningkatkan tingkat gigitan dan perkembangbiakan nyamuk. Hal ini mengakibatkan jumlah nyamuk Aedes aegypti akan meningkat. Semakin banyak jumlah nyamuk Aedes aegyypti maka semakin meningkat pula risiko penularan DBD (Gama dan Nakagoshi, 2013; Morin, Comrie, A.C., dan Ernst, 2013).

Selain faktor iklim, faktor lingkungan lain yang berhubungan dengan kejadian DBD adalah kepadatan jentik. Kepadatan jentik di Indonesia dapat dilihat dari Angka Bebas Jentik (ABJ). ABJ merupakan persentase rumah dan/atau tempat umum yang tidak ditemukan jentik pada kegiatan pemeriksaan jentik berkala (Kemenkes RI, 2011). ABJ dikatakan kurang baik bila ABJ menunjukkan hasil $<95 \%$. ABJ rendah menunjukkan kepadatan jentik di wilayah tersebut masih tinggi. ABJ rendah sangat berperan dalam penularan DBD di suatu wilayah. Daerah yang memiliki kasus demam berdarah tinggi ternyata memiliki ABJ rendah (Hairani, 2009 dan Setyaningsih dan Setyawan, 2014). 
Faktor iklim dan kepadatan jentik yang tinggi menjadi salah satu penyumbang kejadian DBD selalu ada. WHO memperkirakan insiden penyakit DBD mengalami peningkatan selama 30 sampai 50 tahun terakhir. Penyakit DBD menyerang lebih dari 100 juta penduduk tiap tahunnya dengan 500.000 kasus terjadi pada anak-anak dan 30.000 kasus menimbulkan kematian. Penyakit DBD endemis di 100 negara termasuk Asia (Kemenkes RI, 2010). Penyakit DBD banyak ditemukan kasusnya di negara tropis dan subtropis. Dari 2,3 milyar orang yang tinggal di Negara endemis dan berisiko tertular DBD, 1,3 milar orang hidup di 10 negara Asia Tenggara yang termasuk dalam Negara endemis DBD (WHO, 2011).

Kasus DBD pada beberapa tahun terakhir menunjukkan peningkatan di beberapa Negara seperti Thailand, Indonesia dan Myanmar. Negara tersebut termasuk Negara endemis DBD karena penyebaran penyakit DBD sudah sampai ke daerah pedesaan dan bahkan banyak terdapat kasus DBD yang berujung pada kematian (WHO, 2011). Penyakit DBD di Indonesia pertama kali ditemukan di Kota Surabaya pada tahun 1968 yang menginfeksi 58 orang dan 24 orang diantaranya meninggal dunia. World Health Organization (WHO) juga menyatakan bahwa sejak tahun 1968 sampai tahun 2009, Indonesia merupakan Negara yang memiliki kasus DBD tertinggi di Asia Tenggara (Kemenkes RI, 2010).

Hingga sampai saat ini DBD masih menjadi masalah di Indonesia. Semua provinsi di Indonesia pada tahun 2012 sampai 2014 selalu ditemukan kasus DBD. Persentase kabupaten/kota yang ditemukan kasus DBD di wilayahnya adalah sebanyak $83,9 \%$ pada tahun 2012, 82,9\% pada tahun 2013 dan 84,74\% pada tahun 2014 (Kemenkes RI, 2015). Jawa Timur selalu ditemukan kasus DBD selama tahun 2012-2014. Semua kabupaten/kota di Jawa Timur selalu ditemukan kasus DBD (100\%) sehingga menjadikan semua Kabupaten/Kota di Jawa Timur merupakan daerah endemis DBD, termasuk Kota Surabaya. Kejadian DBD tertinggi di Kota Surabaya selama tahun 20102014 terjadi di kecamatan Sawahan dengan jumlah kasus DBD sebanyak 716 kasus.
Kecamatan Sawahan terdiri dari empat puskesmas yaitu Puskesmas Sawahan, Puskesmas Putat Jaya, Puskesmas Banyu Urip dan Puskesmas Pakis dengan kejadian DBD tertinggi terjadi di wilayah kerja Puskesmas Putat Jaya.

Kasus DBD di wilayah kerja Puskesmas Putat Jaya merupakan yang tertinggi di kecamatan Sawahan. Selama tahun 20102014 terdapat 234 kasus DBD. Kejadian DBD di wilayah kerja Puskesmas Putat Jaya selalu ada setiap tahunnya sehingga menunjukkan bahwa kasus DBD masih menjadi masalah di wilayah tersebut setiap tahunnya. Masalah penyakit DBD di Puskesmas Putat Jaya yang selalu ada tidak terlepas dari adanya faktor lingkungan seperti iklim dan ABJ. Penelitian ini bertujuan untuk mengetahui hubungan faktor iklim dan ABJ dengan kejadian DBD di Puskesmas Putat Jaya.

\section{METODE PENELITIAN}

Penelitian termasuk dalam penelitian observasional dengan jenis studi ecology time series. Jenis penelitian adalah penelitian analitik. Waktu pengambilan data dilakukan pada bulan Mei 2016. Populasi adalah semua kasus DBD yang tercatat di Puskesmas Putat Jaya. Tidak dilakukan pengambilan sampel sehingga menggunakan total populasi. Penelitian menggunakan data sekunder berupa data iklim (curah hujan, suhu dan kelembaban), data ABJ dan data kasus DBD di selama tahun 2010-2014. Data sekunder diperoleh dari BMKG Perak Surabaya dan Puskesmas Putat Jaya.

Analisis data diawali dengan melakukan uji normalitas data dengan menggunakan uji Kolmogorov Smirnov. untuk mengetahui kenormalan data. Setelah dilakukan uji normalitas diketahui variabel iklim dan ABJ berdistribusi normal sedangkan variabel kasus DBD tidak berdistribusi normal. Sehingga uji statistik yang digunakan adalah uji korelasi Spearman. Kriteria nilai $\mathrm{r}$ menurut Colton dalam Hairani (2009) adalah:

$r=0,00-0,25$ menunjukkan tidak ada

korelasi/hubungan lemah

$r=0,26-0,50$ menunjukkan korelasi sedang $\mathrm{r}=0,51-0,75$ menunjukkan korelasi kuat 
Tabel 1. Distribusi Frekuensi Kejadian DBD Berdasarkan Umur dan Jenis Kelamin di Puskesmas Putat Jaya Tahun 2010-2014

\begin{tabular}{|c|c|c|c|c|c|c|c|c|c|c|c|c|}
\hline \multirow{3}{*}{ Umur } & \multicolumn{10}{|c|}{ Tahun } & \multirow{2}{*}{\multicolumn{2}{|c|}{ Total }} \\
\hline & \multicolumn{2}{|c|}{2010} & \multicolumn{2}{|c|}{2011} & \multicolumn{2}{|c|}{2012} & \multicolumn{2}{|c|}{2013} & \multicolumn{2}{|c|}{2014} & & \\
\hline & $\mathbf{n}$ & $\%$ & $\mathbf{n}$ & $\%$ & $\mathbf{n}$ & $\%$ & $\mathbf{n}$ & $\%$ & $\mathbf{N}$ & $\%$ & $\mathbf{N}$ & $\%$ \\
\hline$<1$ & 1 & 7,69 & 3 & 23,08 & 3 & 23,08 & 5 & 38,5 & 1 & 7,69 & 13 & 5,56 \\
\hline $1-4$ & 19 & 35,19 & 11 & 20,37 & 2 & 3,7 & 16 & 29,6 & 6 & 11,1 & 54 & 23,07 \\
\hline $5-14$ & 32 & 27,83 & 21 & 18,26 & 20 & 17,39 & 25 & 21,7 & 17 & 14,8 & 115 & 49,15 \\
\hline$\geq 15$ & 15 & 28,85 & 7 & 13,46 & 9 & 17,31 & 11 & 21,2 & 10 & 19,2 & 52 & 22,22 \\
\hline \multirow{3}{*}{$\begin{array}{l}\text { Jenis } \\
\text { Kelamin }\end{array}$} & \multicolumn{10}{|c|}{ Tahun } & \multirow{2}{*}{\multicolumn{2}{|c|}{ Total }} \\
\hline & \multicolumn{2}{|c|}{2010} & \multicolumn{2}{|c|}{2011} & \multicolumn{2}{|c|}{2012} & \multicolumn{2}{|c|}{2013} & \multicolumn{2}{|c|}{2014} & & \\
\hline & $\mathbf{n}$ & $\%$ & $\mathbf{n}$ & $\%$ & $\mathbf{n}$ & $\%$ & $\mathbf{n}$ & $\%$ & $\mathbf{n}$ & $\%$ & $\mathbf{N}$ & $\%$ \\
\hline Laki-laki & 36 & 30,51 & 22 & 18,64 & 12 & 10,17 & 31 & 26,3 & 17 & 14,4 & 118 & 50,43 \\
\hline Perempuan & 31 & 26,72 & 20 & 17,24 & 22 & 18,97 & 26 & 22,4 & 17 & 14,6 & 116 & 49,57 \\
\hline
\end{tabular}

$\mathrm{r}=0,76-1,00$ menunjukkan korelasi sangat kuat/sempurna

\section{HASIL PENELITIAN DAN PEMBAHASAN \\ Gambaran Penyakit DBD di Puskesmas Putat Jaya}

Puskesmas Putat Jaya merupakan salah satu puskesmas yang berada di Kecamatan Sawahan. Puskesmas Putat Jaya terdiri dari satu kelurahan yaitu kelurahan Putat Jaya. Kejadian DBD di Puskesmas Putat Jaya selalu ditemukan setiap tahunnya dengan tren kasus DBD cenderung naik turun. Pada tahun 2010 jumlah kasus DBD cukup tinggi yaitu 67 kasus. Pada tahun selanjutnya terjadi penurunan kasus DBD yaitu terdapat 41 kasus pada tahun 2011 dan 24 kasus pada tahun 2012. Pada tahun 2013 terjadi peningkatan kasus DBD kembali yaitu menjadi 57 kasus. Pada tahun 2014, jumlah kasus DBD mengalami penurunan menjadi 35 kasus DBD. Penderita DBD meninggal juga ditemukan di Puskesmas Putat Jaya yaitu sebanyak satu (1) orang pada tahun 2012 dan 2014.

Kasus DBD berdasarkan umur di Puskesmas Putat Jaya selama tahun 20102014 memiliki pola sama yang mana setiap tahunnya yaitu kasus terbanyak terjadi pada golongan umur 5-14 tahun. Selanjutnya kasus DBD banyak terjadi pada anak usia 1-4 tahun. Kejadian DBD pada orang dewasa berada pada tempat ketiga dan paling sedikit terjadi pada bayi ( $<1$ tahun) (Tabel 1). Tingginya kejadian DBD pada usia 5-14 tahun bisa dikarenakan sistem imunitas (kekebalan) tubuh anak cenderung relatif lebih rendah dibandingkan orang dewasa. Sistem imunitas yang rendah akan membuat tubuh lebih rentan terkena berbagai macam penyakit, termasuk penyakit DBD (Bravo et al., 2014 dan Ginanjar, 2008). Selain itu, usia 5-14 tahun termasuk usia anak sekolah. Anak sekolah dapat tertular penyakit DBD dari dua sumber yaitu lingkungan rumah dan/atau lingkungan sekolah. Anak beraktivitas di sekolah pada pagi hari dan berada di rumah pada sore hari. Pola aktivitas ini sesuai dengan kebiasaan menggigit nyamuk Aedes aegypti yang menggigit pada pagi hari dan sore hari. Nyamuk Aedes aegypti infektif bisa menggigit anak sekolah di pagi hari lalu anak yang terinfeksi dapat membawa dan menyebarkan virus dengue di rumah (Hairani, 2009).

Persentase kejadian DBD pada laki-laki dan perempuan secara total adalah $50,43 \%$ dan 49,57\%. Kejadian DBD berdasarkan jenis kelamin tidak menunjukkan perbedaan Jika dilihat berdasarkan jenis kelamin, kejadian DBD di Puskesmas Putat Jaya tidak menunjukkan perbedaan yang besar. Selama ini belum ada penelitian yang menyebutkan perbedaan kerentanan antara laki-laki dan perempuan terhadap kejadian DBD (Ginanjar, 2008) (Tabel 1).

\section{Curah Hujan dengan Kejadian DBD}




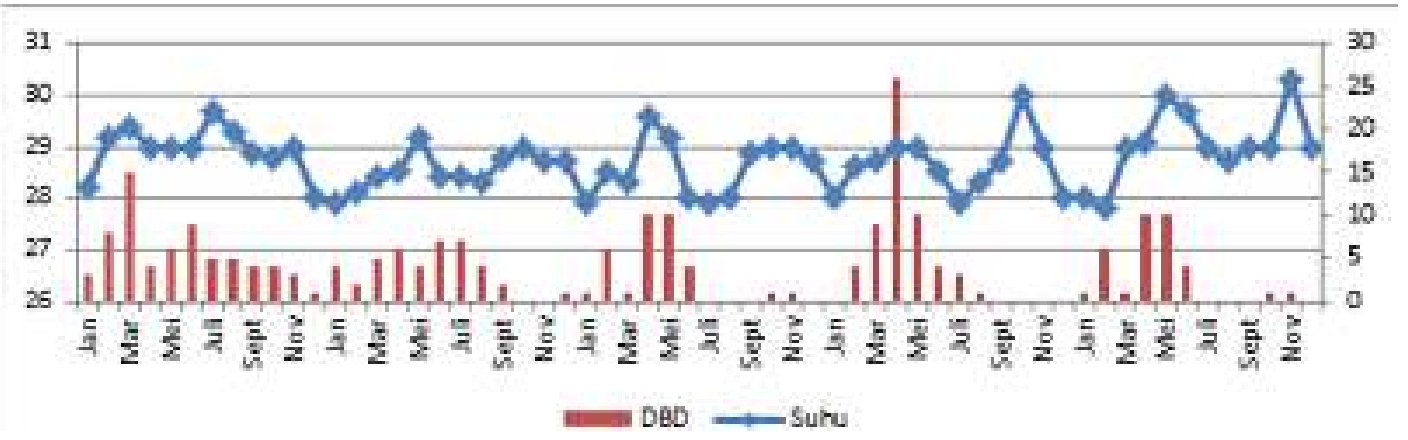

Gambar 2. Grafik Hubungan Suhu dengan Kejadian DBD Puskesmas Putat Jaya Tahun 2010-2014

Pada tahun 2010 curah hujan tertinggi pada bulan Februari sedangkan kasus DBD tertinggi terdapat pada bulan Maret. Pada tahun 2011 curah hujan tertinggi pada bulan Maret sedangkan kasus DBD tertinggi terdapat pada bulan Juni dan Juli. Pada tahun 2012 curah hujan tertinggi pada bulan Maret sedangkan kasus DBD tertinggi terdapat pada bulan April dan Mei. Pada tahun 2013 curah hujan tertinggi pada bulan Januari sedangkan kasus DBD tertinggi terdapat pada bulan April. Pada tahun 2014 curah hujan tertinggi pada bulan Februari sedangkan kasus DBD tertinggi terdapat pada bulan April dan Mei (Gambar 1). Berdasarkan hasil uji korelasi, hubungan antara curah hujan dengan kejadian DBD memiliki kekuatan hubungan yang lemah $(\mathrm{r}=0,141)$ dan arah hubungan positif.

\section{Suhu dengan Kejadian DBD}

Pada tahun 2010 kasus DBD tertinggi terjadi pada bulan Maret dengan suhu $29,2^{\circ} \mathrm{C}$. Pada tahun 2011 kasus DBD tertinggi terjadi pada bulan Juni dan Juli dengan suhu $28,4^{\circ} \mathrm{C}$. Pada tahun 2012 kasus DBD tertinggi terjadi pada bulan April dan Mei dengan suhu $29,6^{\circ} \mathrm{C}$ dan $29,6^{\circ} \mathrm{C}$. Pada tahun 2013 kasus DBD tertinggi terjadi pada bulan April dengan suhu $29^{\circ} \mathrm{C}$. Pada tahun 2014 kasus DBD tertinggi terjadi pada bulan April dan Mei dengan suhu $29,1^{\circ} \mathrm{C}$ dan $30^{\circ} \mathrm{C}$ (Gambar 2). Suhu rata-rata di Puskesmas Putat Jaya selama tahun 20102014 adalah $28,7^{\circ} \mathrm{C}$ dengan rentang suhu berkisar pada $27,9^{\circ} \mathrm{C}-30,3^{\circ} \mathrm{C}$.

Suhu di Puskesmas Putat Jaya merupakan suhu yang cukup optimum untuk perkembangbiakan nyamuk. Berdasarkan hasil uji korelasi, hubungan suhu dengan kejadian DBD di Puskesmas Putat Jaya menunjukkan kekuatan hubungan yang sedang $(r=0,301)$ dan arah hubungan yang positif.

\section{Kelembaban dengan Kejadian DBD}

Kasus DBD di Puskesmas Putat Jaya banyak terjadi pada saat kelembaban udara juga cukup tinggi. Hal ini terlihat terutama pada tahun 2012 sampai tahun 2014. Pada tahun 2010, kasus DBD tertinggi terjadi pada bulan Maret dengan kelembaban 77\%. Pada tahun 2011, kasus DBD tertinggi terjadi pada bulan Juni dan Juli dengan kelembaban $70 \%$

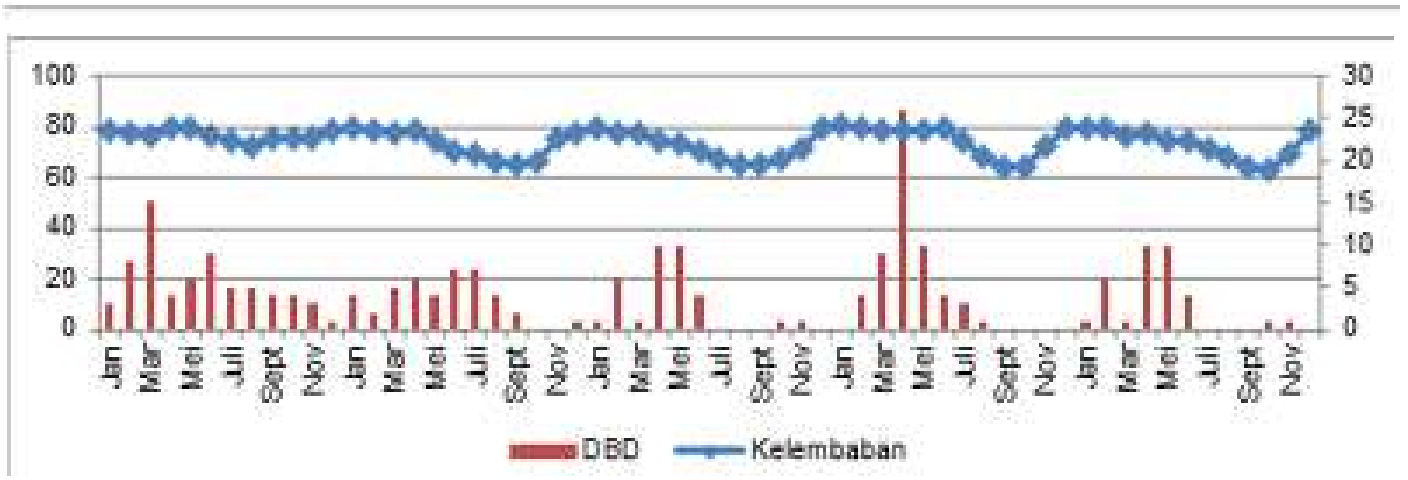

Gambar 3. Grafik Hubungan Kelembaban dengan Kejadian DBD 
dan 69\%. Pada tahun 2012, kasus DBD tertinggi terjadi pada bulan April dan Mei dengan kelembaban sebesar $74 \%$ dan $73 \%$. Pada tahun 2013, kasus DBD tertinggi terjadi pada bulan April dengan kelembaban sebesar 79\%. Pada tahun 2014, kasus DBD tertinggi terjadi pada bulan April dan Mei dengan kelembaban sebesar 78\% dan 75\% (Gambar 3). Kelembaban di wilayah kerja Puskesmas Putat Jaya tahun 2010-2014 berada pada rentang $65 \%$ sampai $81 \%$ dengan nilai ratarata $74,2 \%$. Berdasarkan hasil uji korelasi, hubungan antara kelembaban dengan kejadian DBD di Puskesmas Putat Jaya menunjukkan kekuatan hubungan yang lemah $(\mathrm{r}=0,23)$ dan arah hubungan yang positif.

\section{Angka Bebas Jentik dengan Kejadian DBD}

ABJ menunjukkan kepadatan jentik di suatu wilayah. ABJ yang rendah menunjukkan tingginya kepadatan jentik dan populasi nyamuk Aedes aegypti di wilayah tersebut. ABJ yang rendah sangat berperan terhadap penularan dan penyebaran penyakit DBD (Hairani, 2009). Hubungan ABJ dengan kejadian DBD menunjukkan kekuatan hubungan yang lemah dan arah hubungan yang positif $(\mathrm{r}=0,078)$.

ABJ di Puskesmas Putat Jaya selama tahun 2010-2014 belum pernah memenuhi standar Nasional (ABJ $\geq 95 \%$ ). Apabila ABJ $\geq 95 \%$ maka diharapkan penularan DBD wilayah tersebut dapat dikurangi (Kemenkes RI, 2011).

ABJ di Puskesmas Putat Jaya yang rendah menunjukkan bahwa kepadatan jentik dan populasi nyamuk di Puskesmas Putat Jaya masih tinggi sehingga berisiko DBD. Hal ini dapat dilihat dengan selalu ditemukannya kasus DBD setiap tahunnya selama tahun 2010-2014. ABJ terendah terjadi pada bulan Oktober 2013 sebesar 71,66\% dan ABJ tertinggi terjadi pada bulan Juli 2014 sebesar 91,18\%. Walaupun terjadi kenaikan ABJ setiap tahunnya, hal ini tetap menjadikan wilayah kerja Puskesmas Putat Jaya merupakan wilayah risiko tinggi penularan DBD (Gambar 4).

\section{PEMBAHASAN}

\section{Curah Hujan dengan Kejadian DBD}

Curah hujan diketahui memegang peranan penting dalam penularan penyakit DBD. Hal ini berarti peningkatan curah hujan akan diikuti peningkatan kejadian DBD. Hubungan antara curah hujan dengan kejadian DBD memiliki kekuatan hubungan yang lemah $(r=0,141)$ dan arah hubungan positif.Hasil penelitian sejalan dengan penelitian Pohan (2014) namun berbeda dengan hasil penelitian Dini, Fitriany dan Wulandari (2010).

Curah hujan dapat mempengaruhi kejadian DBD dengan dua cara yaitu meningkatkan kelembaban udara serta menambah tempat perindukan atau breeding place nyamuk Aedes aegypti. Semakin banyak breeding place maka nyamuk Aedes aegypti akan semakin mudah menempatkan telurnya sehingga populasi nyamuk juga akan meningkat. Curah hujan yang tinggi dalam waktu yang lama dapat menyebabkan banjir sehingga menghilangkan tempat perindukan nyamuk Aedes aegypti yang biasanya hidup di air bersih. Hal ini mengakibatkan jumlah perindukan nyamuk akan berkurang sehingga populasi nyamuk Aedes aegypti akan berkurang. Pada musim kemarau, populasi nyamuk Aedes aegypti juga dapat bertambah jika masyarakat menyimpan air dalam tempat penyimpanan air yang akan menjadi breeding place nyamuk Aedes aegypti (Ibarra et al., 2013). Jika curah hujan kecil terjadi dalam waktu yang lama dapat menambah tempat perindukan nyamuk dan meningkatkan populasi nyamuk (Dini, Fitriany dan Wulandari, 2010).

Kekuatan hubungan yang lemah antara curah hujan dengan kejadian DBD dapat terjadi dikarenakan curah hujan yang tinggi justru dapat menghilangkan breeding place atau tempat perindukan nyamuk Aedes aegypti sehingga populasi nyamuk Aedes aegypti juga berkurang. Populasi nyamuk Aedes aegypti yang berkurang akan menurunkan risiko kejadian DBD. Kejadian DBD tertinggi di Puskesmas Putat Jaya setiap tahunnya memang terjadi pada saat musim hujan. Namun, kejadian DBD tertinggi setiap tahunnya terjadi pada saat bukan puncak curah hujan tertinggi.

Suhu dengan Kejadian DBD 


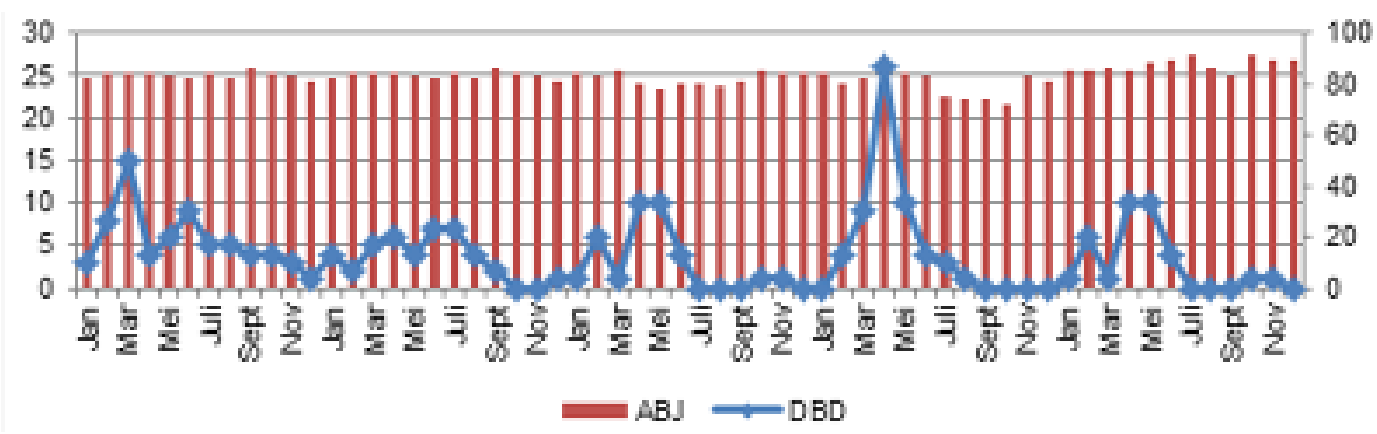

Gambar 4. Grafik Hubungan ABJ dengan Kejadian DBD Puskesmas Putat Jaya Tahun 2010-2014

Hubungan suhu dengan kejadian DBD di Puskesmas Putat Jaya menunjukkan kekuatan hubungan yang sedang $(\mathrm{r}=0,301)$ dan arah hubungan yang positif. Peningkatan suhu akan diikuti dengan peningkatan kejadian DBD. Hasil penelitian ini sejalan dengan penelitian Yuniarti (2009) namun berbeda penelitian Hairani (2009).

Suhu adalah parameter lingkungan yang penting dalam meningkatkan perkembangbiakan vektor, siklus gonotropik nyamuk, tingkat gigitan, memperpendek periode inkubasi patogen inkubasi dan memperpanjang umur nyamuk dewasa. Selain itu, suhu yang lebih tinggi juga meningkatkan tingkat perkembangan larva. Pada nyamuk dewasa, suhu yang lebih tinggi dapat meningkatkan tingkat gigitan nyamuk betina (bitting rate). Nyamuk Aedes aegypti betina membutuhkan banyak darah untuk proses pematangan telur. Selain itu, suhu yang lebih tinggi juga dapat mengurangi waktu yang dibutuhkan virus untuk bereplikasi dalam tubuh nyamuk, yang dikenal sebagai masa inkubasi ekstrinsik virus (EIP) dengue. Masa inkubasi ekstrinsik virus dalam tubuh nyamuk yang lebih cepat diimbangi dengan tingkat gigitan nyamuk menjadi lebih sering akan mengakibatkan risiko penularan DBD semakin meningkat pula (Gama dan Nakagoshi, 2013 dan WHO, 2011).

Suhu optimum untuk nyamuk Aedes aegypti berada pada rentang suhu $25^{\circ} \mathrm{C}-27^{\circ} \mathrm{C}$ (Dini, Fitriany dan Wulandari, 2010). Rentang suhu $20^{\circ} \mathrm{C}-30^{\circ} \mathrm{C}$ adalah suhu yang ideal untuk kelangsungan hidup nyamuk pada semua tahapan siklusnya. Masa inkubasi ekstrinsik virus dengue biasanya terjadi dalam waktu 812 hari (Chakraborty, 2008). Masa inkubasi ekstrinsik virus dalam tubuh nyamuk berkurang dari 9 hari pada suhu $26^{\circ} \mathrm{C}$ dan $28^{\circ} \mathrm{C}$ menjadi 5 hari pada suhu $30^{\circ} \mathrm{C}$. Siklus reproduksi nyamuk betina juga dipengaruhi oleh suhu lingkungan yang mana pada suhu $<20^{\circ} \mathrm{C}$ fertilisasi nyamuk betina berkurang. Aktivitas menggigit nyamuk betina juga dipengaruhi oleh suhu lingkungan. Aktivitas menggigit akan berkurang atau terbatas pada suhu $<15^{\circ} \mathrm{C}$ dan $>36^{\circ} \mathrm{C}$. Aktivitas menggigit nyamuk betina yang tinggi akan mengakibatkan penyebaran penyakit DBD meningkat (Morin, Comrie dan Ernst, 2013).

\section{Kelembaban dengan Kejadian DBD}

Hubungan antara kelembaban dengan kejadian DBD di Puskesmas Putat Jaya menunjukkan kekuatan hubungan yang lemah $(\mathrm{r}=0,23)$ dan arah hubungan yang positif. Peningkatan kelembaban akan diikuti dengan peningkatan kejadian DBD. Hasil penelitian ini sejalan dengan penelitian Hairani (2009) namun berbeda dengan hasil penelitian Dini, Fitriany dan Wulandari (2010).

Kelembaban bisa mempengaruhi keberadaan nyamuk karena berhubungan dengan sistem pernafasan nyamuk. Sistem pernafasan nyamuk menggunakan pipa udara (trachea) dengan lubang pada dinding tubuh nyamuk yang disebut spiracle. Spiracle nyamuk berada dalam kondisi terbuka tanpa ada mekanisme untuk mengaturnya sehingga sensitif terhadap kelembaban di lingkungan. Apabila kelembaban di lingkungan rendah maka penguapan air dari dalam tubuh nyamuk akan membuat nyamuk kekurangan cairan tubuh (Dinata dan Dhewantara, 2012).

Vektor nyamuk cukup sensitif terhadap kelembaban. Kemampuan nyamuk dalam bertahan hidup mengalami penurunan pada kondisi kering (Gubler et al., 2001). Tingkat 
kelembaban $60 \%$ adalah batas paling rendah untuk memungkinkan nyamuk dapat bertahan hidup. Pada kelembaban kurang dari 60\%, umur nyamuk akan semakin pendek (Herawati dan Utomo, 2014 dan Susanto, 2013). Kelembaban udara yang tinggi sekitar $85 \%$ akan memperpanjang umur nyamuk (Pohan, 2014). Umur nyamuk yang semakin panjang mengakibatkan frekuensi gigitan nyamuk juga akan meningkat sehingga risiko penularan DBD juga meningkat.

Menurut Ibarra et al (2013), hubungan iklim dengan kejadian DBD dapat bervariasi pada masing-masing komponen iklim. Variasi ini mungkin disebabkan oleh faktor lain seperti praktik penyimpanan air, pengetahuan dan risiko persepsi masyarakat, dan kondisi perumahan.

\section{Angka Bebas Jentik (ABJ) dengan Kejadian DBD}

Hubungan ABJ dengan kejadian DBD menunjukkan kekuatan hubungan yang lemah dan arah hubungan yang positif $(\mathrm{r}=0,078)$. Hal ini menunjukkan bahwa tingkat kepadatan jentik yang semakin tinggi akan diikuti dengan peningkatan kejadian DBD. Kekuatan hubungan yang lemah antara $\mathrm{ABJ}$ dengan kejadian DBD bisa dikarenakan belum tentu semua jentik nyamuk akan berubah menjadi nyamuk infektif. Pelaksanaan program pengendalian DBD seperti larvadisasi rutin akan mempengaruhi perubahan jentik menjadi nyamuk.

Menurut Kemenkes RI (2011), pemberantasan jentik nyamuk Aedes aegypti dapat dilakukan dengan cara Pemberantasan Sarang Nyamuk (PSN) 3M Plus. Selain itu, WHO (2011) menyatakan bahwa pemberantasan jentik dapat dilakukan dengan tiga cara yaitu pemberantasan jentik dengan cara fisik, kimia dan biologi. Pemberantasan secara fisik dapat dilakukan dengan dua metode pengelolaan lingkungan, yaitu:

1. Modifikasi lingkungan, yaitu melakukan perubahan lingkungan yang bersifat menetap pada tempat perindukan vektor. Hal ini dapat dilakukan dengan cara:

a. Perbaikan distribusi air

Suplai air bersih ke rumah tangga dengan kualitas, kuantitas dan kontinuitas yang baik sehingga mengurangi

kemungkinan

penyimpanan air dalam wadah yang dapat berubah fungsi menjadi tempat perindukan nyamuk;

b. Pengeringan air tergenang

Genangan air dar kebocoran pipa, kebocoran tangki air, buangan pendingin udara dan buangan kulkas dapat menjadi tempat perindukan nyamuk sehingga perlu dilakukan pengeringan secara teratur dan penutupan pada tempat yang bocor;

c. Tangki penyimpanan air anti nyamuk atau tangki air bawah tanah

Tangki penyimpanan air dapat menjadi perindukan nyamuk sehingga harus tertutup dengan rapat. Demikian pula dengan tangki air bawah tanah harus dipastikan tidak bisa menjadi perindukan nyamuk.

2. Manipulasi lingkungan, yaitu melakukan perubahan lingkungan yang bersifat tidak menetap pada tempat perindukan vektor dengan cara a) Membersihkan dan menutup tempat penyimpanan air, b) Membersihkan vas/pot bunga, c) Tanaman yang berlubang harus dipotong pada ruasnya, sedangkan pagar dengan kontruksi pipa harus diisi dengan pasir atau semen.

Pemberantasan dengan cara kimia dapat dilakukan dengan menggunakan pestisida pembasmi jentik yaitu larvasida. Larvasida digunakan dengan dosis 1\% atau satu gram (1 sendok makan rata) untuk 100 liter. Pemberantasan jentik dengan cara biologi dapat dilakukan dengan memelihara predator jentik yaitu ikan cupang, ikan kepala timah. Cara lain adalah dengan menggunakan bakteri yaitu bakteri Bacillus thuringiensis (WHO, 2011).

\section{SIMPULAN DAN SARAN}

Hasil uji korelasi Spearman menunjukkan bahwa hubungan curah hujan dengan kejadian DBD memiliki kekuatan hubungan lemah dan arah hubungan positif $(r=0,141)$. Peningkatan curah hujan diikuti dengan peningkatan kejadian DBD. Suhu memiliki kekuatan hubungan sedang dan arah hubungan positif dengan kejadian DBD ( $\mathrm{r}=0,301)$. Peningkatan suhu akan diikuti oleh peningkatan kejadian 
DBD. Kelembaban memiliki kekuatan hubungan lemah dan arah hubungan positif dengan kejadian DBD $(\mathrm{r}=0,23)$. Peningkatan kelembaban akan diikuti oleh peningkatan kejadian DBD.

ABJ Puskesmas Putat Jaya masih belum baik karena ABJ selama tahun 2010-2014 tidak pernah mencapai standar Nasional $\geq 95 \%$. Hubungan antara ABJ dengan kejadian DBD menunjukkan kekuatan hubungan lemah dan arah hubungan positif dengan kejadian DBD $(r=0,078)$. Nilai ABJ yang semakin rendah akan diikuti dengan peningkatan kejadian DBD.

\section{SARAN}

Puskesmas Putat Jaya diharapkan dapat melakukan program pengendalian DBD lebih giat lagi agar kejadian DBD di Puskesmas Putat Jaya dapat ditekan. Selain itu, masyarakat juga berperan dalam mengendalikan penyakit DBD di Puskesmas Putat Jaya. Masyarakat dapat menjaga lingkungannya dengan cara mengurangi breeding place atau tempat perindukan nyamuk Aedes aegypti yang ada di lingkungan rumah. Cara yang dapat dilakukan adalah dengan melakukan kegiatan PSN 3M Plus secara rutin seperti menguras dan menyikat tempat penampungan air (bak mandi, drum, dan lain-lain) minimal seminggu sekali sehingga breeding place nyamuk Aedes aegypti dapat dihilangkan dan risiko kejadian DBD di Puskesmas Putat Jaya dapat diturunkan.

\section{DAFTAR PUSTAKA}

Bravo, L., Roque, V.G., Brett, J., Dizon, R., \& Azou, M.L. 2014. Epidemiology of Dengue Disease in the Philippines (2000-2011): A Systematic Literature Review. PLOS Neglected Tropical Disease Journal, No.11, Vol. 8, November. Diakses dari http://www.ncbi.nlm.nih.gov/pmc/ar ticles/PMC 4222740/.

Brisbois, B.W., \& Ali, S.H. 2010. Climate Change, Vector-borne Disease and Interdisciplinary Research: Social Science Perspectives on an Environment and Health
Controversy. EcoHealth, 7, 425-438.

DOI: 10.1007/s10393-010-0354-6.

Chakraborty, T. 2008. Dengue Fever and

Other Hemorrhagic Viruses. New York: Chelsea House Publishing.

Dinata, A., \& Dhewantara, P.W. 2012. Karakteristik Lingkungan Fisik, Biologi, Dan Sosial Di Daerah Endemis Dbd Kota Banjar Tahun 2011. Jurnal Ekologi Kesehatan, Vol.11, No.4, Desember, hal. 315$326 . \quad$ Diakses dari: http://ejournal.litbang.depkes.go.id/i ndex.php/jek/article/view/3835.

Dini, A.M.V., Fitriany, R.N., \& Wulandari, R.A. 2010. Faktor Iklim dan Angka Insiden Demam Berdarah Dengue di Kabupaten Serang. Jurnal Makara, Kesehatan, Vol.14, No.1, Juni, hal. 31-38. Diakses dari http://journal.ui.ac.id/index.php/heal th/article/viewFile/644/629.

Fidayanto, R., Susanto, H., Yohanan, A., \& Yudhastuti, R. 2013. Model Pengendalian Demam Berdarah Dengue. Jurnal Kesehatan Masyarakat Nasional Vol.7, No.11, Juni, hal. 522-528. Diakses dari http://jurnalkesmas.ui.ac.id/index.ph $\mathrm{p} /$ kesmas/article/viewFile/366/365.

Ginanjar G. 2008. Demam Berdarah: $A$ Survival Guide. Jakarta: PT Bentang Pustaka.

Gama, Z.P., \& Nakagoshi, N. 2013. Climatic Variability and Dengue Haemaorrhagic Fever Incidence in Nganjuk District, East Java, Indonesia. Jurnal Acta Biologica Malaysiana 2(1), hal. 31-39. Diakses dari https://www.researchgate.net/ publication/281204374_Climatic_Variability _and_Dengue_Haemaorrhagic_Feve r_Incidence_in_Nganjuk_District_E ast Java Indonesia.

Gubler, D.J., Reiter, P., Ebi, K.L., Yap, W., Nasci, R., \& Patz, J.A. 2001. Climate Variability and Change in the United States: Potential Impacts on Vectorand Rodent-Borne Diseases. Environmental Health Perspective, Vol. 109, Supplement 2, Mei. Diakses dari 
http://www.ncbi.nlm.nih.gov/pmc/ar ticles/PMC1240669/.

Hairani, L.K. 2009. Gambaran Epidemiologi Demam Berdarah Dengue (DBD) Dan Faktor-Faktor Yang Mempengaruhi Angka Insidennya di Wilayah Kecamatan Cimanggis Kota Depok Tahun 2005-2008 (Skripsi, Universitas Indonesia). Diakses dari http://www.lib.ui.ac.id.

Herawati, Y., \& Utomo, S.W. 2014. The Dynamics of Population Density and Climate Variability on Dengue Hemorrhagic Fever (DHF) Incidence in Bogor City, West Java, Indonesia. Research Journal of Social Science and Management, Vol.4, No.4, Agustus, hal. 160-165. Diakses dari http://www.theinternationaljournal.o rg/ojs/index.php?journal=tij\&page $=$ article\&op=view\&path $\% 5 \mathrm{~B} \% 5 \mathrm{D}=3$ 141.

Ibarra, A.M.S., Ryan, S.J., Beltran, E., Mejia, R., Silva, M., dan Munoz, A., 2013. Dengue Vector Dynamics (Aedes aegypti) Influenced by Climate and Social Factors in Ecuador: Implications for Targeted Control. PLOS One Journal, Vol. 8, No.11, November. Diakses dari http://journals.plos.org/plosone/artic le?id=10.1371/journal.pone.007826 3.

Kemenkes RI. 2010. Buletin Jendela Epidemiologi, Vol. 2, Agustus. Jakarta: Pusat Data dan Surveilans Epidemiologi Kementerian Kesehatan Republik Indonesia.

Kemenkes RI. 2011. Modul Pengendalian Demam Berdarah Dengue. Jakarta: Direktorat Jenderal Pengendalian Penyakit dan Penyehatan Lingkungan.

Kemenkes RI. 2015. Profil Kesehatan Indonesia 2014. Jakarta: Kementerian Kesehatan Republik Indonesia.

Morin, C.W., Comrie, A.C., \& Ernst, K. 2013. Climate and Dengue Transmission: Evidence and Implications. Environmental Health Prespective,
Vol.121, No.11-12, Nov-Dec. DOI:10.1289/ehp.1306556.

Pohan, Z. 2014. Hubungan Iklim Terhadap Kasus Demam Berdarah Dengue (DBD) di Kota Palembang Tahun 2003-2013 (Skripsi, Universitas Sriwijaya). Diakses dari www.unsri.ac.id.

Susanto, H., 2013. Analisis Pengaruh Iklim Dan Perilaku Masyarakat Terhadap Kepadatan Jentik Nyamuk Aedes Aegypti Dan Kejadian Demam Berdarah Dengue: Studi Di Wilayah Pelabuhan Laut Tanjung Perak Surabaya (Thesis tidak dipublikasikan). Universitas Airlangga Surabaya.

WHO. 2011. Comprehensive Guidelines for Prevention and Control of Dengue and Dengue Hemorrhagic Fever. India: World Health Organization.

Yuniarti, A. 2009. Hubungan Iklim (Curah Hujan, Kelembaban dan Suhu Udara) dengan Kejadian Penyakit Demam Berdarah Dengue (DBD) di Kota Administrasi Jakarta Timur Tahun 2004-2008 (Skripsi, Universitas Indonesia). Diakses dari http://www.lib.ui.ac.id. 